\title{
Livestock markets play an important role in the cattle movement network in Pernambuco, Brazil
}

\author{
Feiras de gado desempenham papel importante \\ na rede de trânsito de bovinos em Pernambuco, Brasil
}

\author{
José Lopes SILVA JÚNIOR ${ }^{1,2}$; Erivânia Camelo ALMEIDA²; Fabíola Nascimento CORRÊA3; \\ Paula Regina Barros LIMA ${ }^{1,2}$; Raul OSSADA ${ }^{4}$; Fernando Silveira MARQUES ${ }^{4}$; Ricardo Augusto DIAS ${ }^{4}$; \\ Fernando FERREIRA'; José Soares FERREIRA NETO'; José Henrique Hildebrand GRISI-FILHO;; \\ Marcos AMAKU ${ }^{4,5}$; Hélio Cordeiro MANSO FILHO; ${ }^{6}$ Jean Carlos Ramos SILVA ${ }^{1}$ \\ ${ }^{1}$ Universidade Federal Rural de Pernambuco, Departamento de Medicina Veterinária, Recife - PE, Brazil \\ ${ }^{2}$ Agência de Defesa e Fiscalização Agropecuária de Pernambuco, Recife - PE, Brazil \\ ${ }^{3}$ Ministério da Agricultura, Pecuária e Abastecimento, Laboratório Nacional Agropecuário, Recife - PE, Brazil \\ ${ }^{4}$ Universidade de São Paulo, Faculdade de Medicina Veterinária e Zootecnia, \\ Departamento de Medicina Veterinária Preventiva e Saúde Animal, São Paulo - SP, Brazil \\ ${ }^{5}$ Universidade de São Paulo, Faculdade de Medicina, São Paulo - SP, Brazil \\ ${ }^{6}$ Universidade Federal Rural de Pernambuco, Departamento de Zootecnia, Recife - PE, Brazil
}

\begin{abstract}
The animal trade is an important risk factor that affects the spread of diseases among animals and herds. The goal of the present study was to characterize the cattle movement network in Pernambuco, Brazil, based on the animal movement permits (Guias de Trânsito Animal; GTAs) from 2012 to 2013, and identify the intensity of the commercial relationship between farm premises. A total of 737,950 GTAs were issued, and the movement of 3,481,185 cattle $(1,688,585$ in 2012 and 1,792,600 in 2013) was analyzed. Of the moved animals analyzed, $52.57 \%(1,829,907 / 3,481,185)$ were involved in the movement of cattle in or out of livestock markets, indicating that livestock markets played a major role in the network. Approximately $20 \%$ of the more-connected premises were responsible for approximately $87 \%$ of the movement related to sales and $95 \%$ of the movement related to purchases. Considering the important role of livestock markets and the intense cattle trade between farm premises, surveillance, and control measures could be more efficient if targeted to livestock markets and highly connected premises to prevent the spread of infectious diseases.
\end{abstract}

Keywords: Animal movement. Official veterinary service. Network. Epidemiological surveillance.

\section{Resumo}

O comércio de animais é um importante fator de risco para a disseminação de doenças entre animais e rebanhos. O objetivo do presente estudo foi caracterizar a rede de movimentação de bovinos em Pernambuco, com base nas guias de trânsito animal (GTAs) de 2012 a 2013, e identificar a intensidade da relação comercial entre os estabelecimentos. Foram analisadas 737.950 GTAs emitidas, e as movimentações de bovinos totalizaram 3.481.185 animais (1.688.585 em 2012 e 1.792 .600 em 2013). Um percentual de 52,57\% (1.829.907/3.481.185) das movimentações de bovinos envolveu entrada ou saída de feiras de gado, indicando que as feiras desempenharam um papel importante na rede. Aproximadamente $20 \%$ dos estabelecimentos mais conectados foram responsáveis por aproximadamente $87 \%$ das movimentações relacionadas às vendas, e $95 \%$ das movimentações, relacionadas às compras. Considerando o importante papel das feiras e o intenso comércio de bovinos entre as propriedades, medidas de vigilância e controle podem ser mais eficientes se aplicadas em feiras e estabelecimentos altamente conectados, para prevenir a propagação de doenças infecciosas.

Palavras-chave: Trânsito animal. Serviço veterinário oficial. Rede. Vigilância epidemiológica. 


\section{Correspondence to:}

Marcos Amaku

Universidade de São Paulo, Faculdade de Medicina Veterinária

e Zootecnia, Departamento de Medicina Veterinária Preventiva

e Saúde Animal

Av. Prof. Dr. Orlando Marques de Paiva, 87

CEP 05508-270, São Paulo, SP, Brazil

e-mail: amaku@vps.fmvz.usp.br

Received: 15/12/2016

Approved: 07/08/2017

\section{Introduction}

The intense movement of farm animals between premises is of great economic relevance to the northeastern region of Brazil and especially to Pernambuco (PE). In agro-productive systems, however, animal movement might represent a risk factor because it can facilitate the spread of several diseases (BIGRAS-POULIN et al., 2006; RIBEIRO, 2009).

The characterization of animal movement networks allows for inferences regarding the potential risks associated with agricultural niches, the identification of current or future groups at risk of disease transmission, and the generation of knowledge concerning the business dynamics and forms of production in these regions. The identification of concentrations of epidemiological units in specific regions and the visualization of these areas on georeferenced maps are epidemiological tools that can explain the livestock-production system (AMADOR et al., 2009; WHITE et al., 2010), aiding decision making and the application of sanitary measures.

Social network analysis has been shown to be a valuable framework for studying animal movement networks, as well as the dynamics and control of diseases in these networks (MWEU et al., 2013). A network of livestock movements may be composed of different types of premises (for instance beef, dairy, breeder, dealer, live cattle market, auction market, and slaughterhouse). Different types of nodes have been shown to be the key players in some cattle movement networks: the key players in a network in Cambodia were producers who raised their cattle as backyard animals (POOLKHET et al., 2016); traders were the nodes with high values of centrality in a network in Thailand (NOOPATAYA et al., 2015); and markets were the key influential holdings in the network of Danish cattle (MWEU et al., 2013). In particular, markets played important roles in the spread of infectious diseases. For instance, in the spread of footand-mouth disease virus during the 2001 Great Britain epidemic, an important factor was the movement of animals through markets (ROBINSON; CHRISTLEY, 2007).

To characterize the networks of animal movements using data recorded in Brazil, it is necessary to record the issuing of animal movement permits (Guia de Trânsito Animal; GTAs), i.e., the mandatory official document for the movement of live animals (except domestic cats and dogs), fertile eggs, and other materials needed for animal reproduction across the country. GTAs contain information on the origin, destination, and sanitary conditions of animals as well as the premises of the origin and purpose of the animal movement (BRASIL, 2006). Studies conducted in Brazil used GTAs as data source in order to examine the performance of epidemiological surveys of brucellosis and bovine tuberculosis (ALMEIDA, 2013), the expansion of the foot-and-mouth disease-free zone (BRASIL, 2013), the characterization of the movement of cattle (NEGREIROS, 2010), and the evaluation and implementation of epidemiological models of disease transmission (PENA, 2011).

There are potential limitations or bias that may arise from the use of GTAs to characterize the network. As discussed by Amaku et al. (2015), the survey of the entire animal movement network is not always possible, either because the data are insufficient or because informal trade is significant. Thus, the use of GTAs to characterize the network has potential limitations when the data are insufficient (when the GTA database is incomplete, for example) or informal (not registered) trade is significant.

In northeastern Brazil there are peculiarities that can influence animal movement and the epidemiology of disease transmission. In Pernambuco two million ruminants (out of a population of approximately 6.7 million) are transported each year on average (AGÊNCIA DE DEFESA E FISCALIZAÇÃO AGROPECUÁRIA DE PERNAMBUCO, 2014). The ratio of cattle moved with regard to the total cattle population in Pernambuco is not high, when compared to what has been observed in other Brazilian states, such as Mato Grosso, where 15.8 million cattle were moved in 2007 out of a bovine population of approximately 28.8 million (GRISI-FILHO et al., 2013). The movement pattern of these animals follows different trends, ranging in epidemiological units according to the weather (dry vs. rainy periods) and the occurrence of cattle markets, which are considered an economic and sociocultural activity in certain municipalities in the northeast (SILVA JÚNIOR et al., 2012). 
For this reason, the present study aimed at characterizing the cattle movement network in Pernambuco, particularly the role of cattle markets, based on the GTAs issued by the Agência de Defesa e Fiscalização Agropecuária de Pernambuco (ADAGRO) from January 2012 to December of 2013, as well as identifying the intensity of the commercial relationships between premises.

\section{Materials and Methods}

Pernambuco state has a geographical area of $98,938 \mathrm{~km}^{2}$, not including the $18.2 \mathrm{~km}^{2}$ that belongs to the Fernando de Noronha Archipelago. It has 184 municipalities and is divided into three major geo-economic regions: the coast/ Zona da Mata, Agreste, and Sertão. These last two regions comprise an area of $87,317 \mathrm{~km}^{2}$ including the Drought Polygon; this area corresponds to $88.84 \%$ of the territory of PE. A total of 97,433 production-animal breeding premises, 100,578 rural farmers, and 1,977,693 cattle are registered with ADAGRO. Currently 166 slaughterhouses exist in the area. A total of 51 cattle are held weekly in PE, where a large quantity of production animals (mostly cattle, goats, and sheep) is assembled.

From January 2012 to December 2013, the issuance of computerized GTAs was conducted online via the Agricultural Integration System of ADAGRO, and the data were generated in May 2014. Reports were generated from the intrastate and interstate movement records of animals and organized into spreadsheets, excluding data on other species using only those records on cattle movement. Prior organization was necessary for database analysis purposes, and the following variables were defined: movement purpose, total number of animals, premises of origin code, destination city, the Natural Persons Register (Cadastro de Pessoas Físicas; CPF) or the National Registry of Legal Entities (Cadastro Nacional da Pessoa Jurídica; CNPJ) documents, premises of destination code, and the name of the destination property. Some of the premises located in Pernambuco and those in other Federation Units (FUs) did not have a single premise code; therefore, it was necessary to conduct a recode so that one unique code was assigned to each premise. To analyze the results obtained in the present study, each GTA issued was considered a batch of transported cattle, and each premises represented a "node" (i.e., a property, event, or slaughterhouse).

For the descriptive analysis of the cattle movement data, tables and graphs were compiled regarding the quantitative parameters (absolute and relative values) of the cattle moved per movement purpose, the premises of the destination, the egress from the cattle markets by type of destination premises, and the type of movement within Pernambuco (intrastate movement) and across other states (interstate movement).

In the analysis based on the type of destination premises, the category "events" covered all of the GTAs issued with the purpose of export, exhibition/auction, animal markets, and others; the category "property" encompassed the GTAs issued regarding farming/finishing or farming/breeding; and the category "slaughter" recorded the GTAs issued for groups of animals destined for slaughter.

Cattle premises were considered as nodes of the animal movement network. The following variables were calculated in the analysis of network parameters: the indegree of the node, $k_{\text {in }}$ given by the number of premises that sell animals to that node; the out-degree of the node, $k_{\text {out }}$ given by the number of premises that buy animals from that node; and the total degree, $k$, which is the sum of the in-degree and the out-degree. Both $k_{\text {in }}$ and $k_{\text {out }}$ can be weighted by the number of batches or number of animals.

An analysis of degree distribution, $P(k)$, was performed. $P(k)$ is given by the relative frequency of the nodes with degree $k$ in the network. For the fitting of $P(k)$, a powerlaw $P(k)=C \mathrm{e}^{-\mathrm{ak}}$ was used, where $C$ and $\alpha$ are the fitting parameters. The fitting was carried out using the poweRlaw package in R (GILLESPIE, 2015).

Another analysis was performed to assess the assortativity of the network, in which the average degree of the neighboring nodes in the network is analyzed as a function of the degree of a given node.

For the statistical analysis, the data from the movement of cattle were analyzed using $\mathrm{R}$ (R DEVELOPMENT CORE TEAM, 2015) and the igraph package (CSARDI; NEPUSZ, 2006) to better understand the behavior of the cattle movement network and its peculiarities as described by Negreiros (2010) and Grisi-Filho et al. (2013).

\section{Results}

From January 2012 to December 2013, 993,313 GTAs were issued for all animal species $(489,103$ in 2012 and 504,210 in 2013). Of these GTAs, 737,950 were issued for cattle in Pernambuco (372,521 in 2012 and 365,429 in 2013). Of the $3,481,185$ cattle moved during the study time period, 3,179,412 (91.33\%) were destined for premises located in Pernambuco, and 301,773 (8.67\%) were moved to other states (Table 1). 
Table 1 - The distribution of the intrastate and interstate movement of cattle in Pernambuco according to movement purpose in 2012 and 2013 - Pernambuco - 2012-2013

\begin{tabular}{|c|c|c|c|c|c|c|c|c|c|}
\hline \multirow[t]{2}{*}{ Purposes } & \multicolumn{3}{|c|}{ Cattle moved } & \multicolumn{3}{|c|}{$\begin{array}{c}\% \text { relative to total movement in } \\
\text { Pernambuco }\end{array}$} & \multicolumn{3}{|c|}{ Total movement in Pernambuco } \\
\hline & 2012 & 2013 & Total & 2012 & 2013 & $2012 / 2013$ & 2012 & 2013 & Total \\
\hline \multicolumn{10}{|c|}{ Intrastate } \\
\hline Slaughter & 249,002 & 311,064 & 560,066 & $14.75 \%$ & $17.35 \%$ & $16.09 \%$ & 275,271 & 332,971 & 608,242 \\
\hline Farming/Finishing & 663,295 & 754,974 & $1,418,269$ & $39.28 \%$ & $42.12 \%$ & $40.74 \%$ & 768,783 & 849,012 & $1,617,795$ \\
\hline Farming/Reprod & 106,267 & 93,237 & 199,504 & $6.29 \%$ & $5.20 \%$ & $5.73 \%$ & 126,015 & 104,480 & 230,495 \\
\hline Export & 8211 & 10,907 & 19,118 & $0.49 \%$ & $0.61 \%$ & $0.55 \%$ & 8548 & 11,698 & 20,246 \\
\hline Exp/Auction & 400 & 453 & 853 & $0.02 \%$ & $0.03 \%$ & $0.02 \%$ & 404 & 465 & 869 \\
\hline Market & 496,635 & 484,854 & 981,489 & $29.41 \%$ & $27.05 \%$ & $28.19 \%$ & 509,523 & 493,900 & $1,003,423$ \\
\hline Others & 39 & 74 & 113 & $0.00 \%$ & $0.00 \%$ & $0.00 \%$ & 41 & 74 & 115 \\
\hline Total & $1,523,849$ & $1,655,563$ & $3,179,412$ & $90.24 \%$ & $92.36 \%$ & $91.33 \%$ & $1,688,585$ & $1,792,600$ & $3,481,185$ \\
\hline \multicolumn{10}{|c|}{ Interstate } \\
\hline Slaughter & 26,269 & 21,907 & 48,176 & $1.56 \%$ & $1.22 \%$ & $1.38 \%$ & 275,271 & 332,971 & 608,242 \\
\hline Farming/Finishing & 105,488 & 94,038 & 199,526 & $6.25 \%$ & $5.25 \%$ & $5.73 \%$ & 768,783 & 849,012 & $1,617,795$ \\
\hline Farming/Reprod & 19,748 & 11,243 & 30,991 & $1.17 \%$ & $0.63 \%$ & $0.89 \%$ & 126,015 & 104,480 & 230,495 \\
\hline Export & 337 & 791 & 1128 & $0.02 \%$ & $0.04 \%$ & $0.03 \%$ & 8548 & 11,698 & 20,246 \\
\hline Exp/Auction & 4 & 12 & 16 & $0.00 \%$ & $0.00 \%$ & $0.00 \%$ & 404 & 465 & 869 \\
\hline Market & 12,888 & 9046 & 21,934 & $0.76 \%$ & $0.50 \%$ & $0.63 \%$ & 509,523 & 493,900 & $1,003,423$ \\
\hline Others & 2 & 0 & 2 & $0.00 \%$ & $0.00 \%$ & $0.00 \%$ & 41 & 74 & 115 \\
\hline Total & 164,736 & 137,037 & 301,773 & $9.76 \%$ & $7.64 \%$ & $8.67 \%$ & $1,688,585$ & $1,792,600$ & $3,481,185$ \\
\hline
\end{tabular}

Legend: Farming/Reprod = Farming/Reproduction; Exp/Auction = Exposition/Auction

The cattle movement data based on the type of destination premises are shown in table 2 . The distribution of exits from cattle markets based on the type of destination premise and the cattle movement data based on the type of movement are shown in table 3 . The parameters of the movement network for cattle and batches of cattle are presented in table 4 .

Table 2 - The distribution of the intrastate and interstate movement of cattle in Pernambuco according to type of destination premise in 2012 and 2013 - Pernambuco - 2012-2013

\begin{tabular}{|c|c|c|c|c|c|}
\hline Premises & Intrastate & $\begin{array}{l}\% \text { relative to total } \\
\text { movement in } \\
\text { Pernambuco }\end{array}$ & Interstate & $\begin{array}{l}\% \text { relative to total } \\
\text { movement in } \\
\text { Pernambuco }\end{array}$ & Total \\
\hline Event & $1,001,486$ & $28.77 \%$ & 23,078 & $0.66 \%$ & $1,024,564$ \\
\hline Slaughterhouse & 560,066 & $16.09 \%$ & 48,176 & $1.38 \%$ & 608,242 \\
\hline Farm & $1,617,860$ & $46.47 \%$ & 230,519 & $6.62 \%$ & $1,848,379$ \\
\hline Total & $3,179,412$ & $91.33 \%$ & 301,773 & $8.67 \%$ & $3,481,185$ \\
\hline
\end{tabular}


Table 3 - The distribution of the intrastate and interstate movement of cattle in Pernambuco according to transport type in 2012 and 2013. At the bottom of the table, the distribution of the intrastate and interstate movement of cattle across cattle markets in Pernambuco according to type of destination premise - Pernambuco - 2012-2013

\begin{tabular}{|c|c|c|c|c|c|c|c|c|c|c|}
\hline \multirow[b]{2}{*}{ Transport } & \multicolumn{2}{|c|}{ Intrastate } & \multicolumn{2}{|c|}{$\begin{array}{l}\% \text { relative to total } \\
\text { movement in } \\
\text { Pernambuco }\end{array}$} & \multicolumn{2}{|c|}{ Interstate } & \multicolumn{2}{|c|}{$\begin{array}{l}\% \text { relative to total } \\
\text { movement in } \\
\text { Pernambuco }\end{array}$} & \multicolumn{2}{|c|}{ Total } \\
\hline & Animals & Batches & Animals & Batches & Animals & Batches & Animals & Batches & Animals & Batches \\
\hline By foot & 142,763 & 30,500 & 4.49 & 4.29 & 2,379 & 173 & 0.79 & 0.66 & 145,142 & 30,673 \\
\hline Highway & $3,036,649$ & 681,189 & 95.51 & 95.71 & 299,394 & 26,089 & 99.21 & 99.34 & $3,336,043$ & 707,278 \\
\hline Total & $3,179,412$ & 711,689 & 100 & 100 & 301,773 & 26,262 & 100 & 100 & $3,481,185$ & 737,951 \\
\hline \multicolumn{11}{|c|}{ Movement across cattle markets } \\
\hline Destination & Animals & Batches & Animals & Batches & Animals & Batches & Animals & Batches & Animals & Batches \\
\hline Event & 253 & 65 & 0.03 & 0.02 & 101 & 25 & 0.30 & 0.23 & 354 & 90 \\
\hline Slaughterhouse & 116,171 & 53,471 & 14.66 & 20.48 & 10,905 & 4542 & 32.17 & 42.52 & 127,076 & 58,013 \\
\hline Farm & 676,165 & 207,569 & 85.31 & 79.50 & 22,889 & 6116 & 67.53 & 57.25 & 699,054 & 213,685 \\
\hline Total & 792,589 & 261,105 & 100 & 100 & 33,895 & 10,683 & 100 & 100 & 826,484 & 271,788 \\
\hline
\end{tabular}

Table 4 - The cattle movement network parameters in Pernambuco according to the indegree $\left(k_{\text {in }}\right)$, outdegree $\left(k_{\text {out }}\right)$, and total degree $(k)$ of neighbors, batches of cattle, and cattle in 2012 and 2013 - Pernambuco - 2012-2013

\begin{tabular}{|c|c|c|c|c|c|c|}
\hline Indegree, outdegree, degree & Min & 1st Quartile & Median & Mean & 3rd Quartile & Max \\
\hline$k_{\text {in }}$ (neighbors) & 0 & 0 & 1 & 2.278 & 1 & 8,599 \\
\hline$k_{\text {out }}$ (neighbors) & 0 & 1 & 1 & 2.278 & 2 & 5,420 \\
\hline$k$ (neighbors) & 1 & 1 & 2 & 4.091 & 3 & 10,540 \\
\hline$k_{\text {in }}$ (batches) & 0 & 0 & 1 & 7.12 & 2 & 32,420 \\
\hline$k_{\text {out }}$ (batches) & 0 & 1 & 2 & 7.12 & 4 & 48,830 \\
\hline$k$ (batches) & 1 & 1 & 2 & 14.25 & 6 & 81,250 \\
\hline$k_{\text {in }}$ (cattle) & 0 & 0 & 2 & 33.53 & 7 & 195,300 \\
\hline$k_{\text {out }}$ (cattle) & 0 & 1 & 5 & 33.53 & 15 & 164,700 \\
\hline k (cattle) & 1 & 3 & 9 & 67 & 23 & 360,000 \\
\hline
\end{tabular}

Out of the 738,010 GTA records analyzed, 60 (0.00811\%) were lost because of a lack of origin code premises, leaving 737,950 GTAs, 103,351 premises, and 3,464,935 cattle moved for the network analysis. Of these premises, 102,834
(99.5\%) were farms, 337 (0.326\%) were slaughterhouses, and $180(0.174 \%)$ were markets.

To illustrate the cattle movement network, a map of the animal movement between the municipalities of Pernambuco 
during June 2012 was created (Figure 1). Boxplots and graphs were drawn to show the inputs and outputs of cattle (Figure 2) and the cattle batches (Figure 3) from the premises as well as the relationship between the number of cattle purchased and sold according to the type of premise of origin and destination (property, event, or slaughterhouse) (Figure 4).

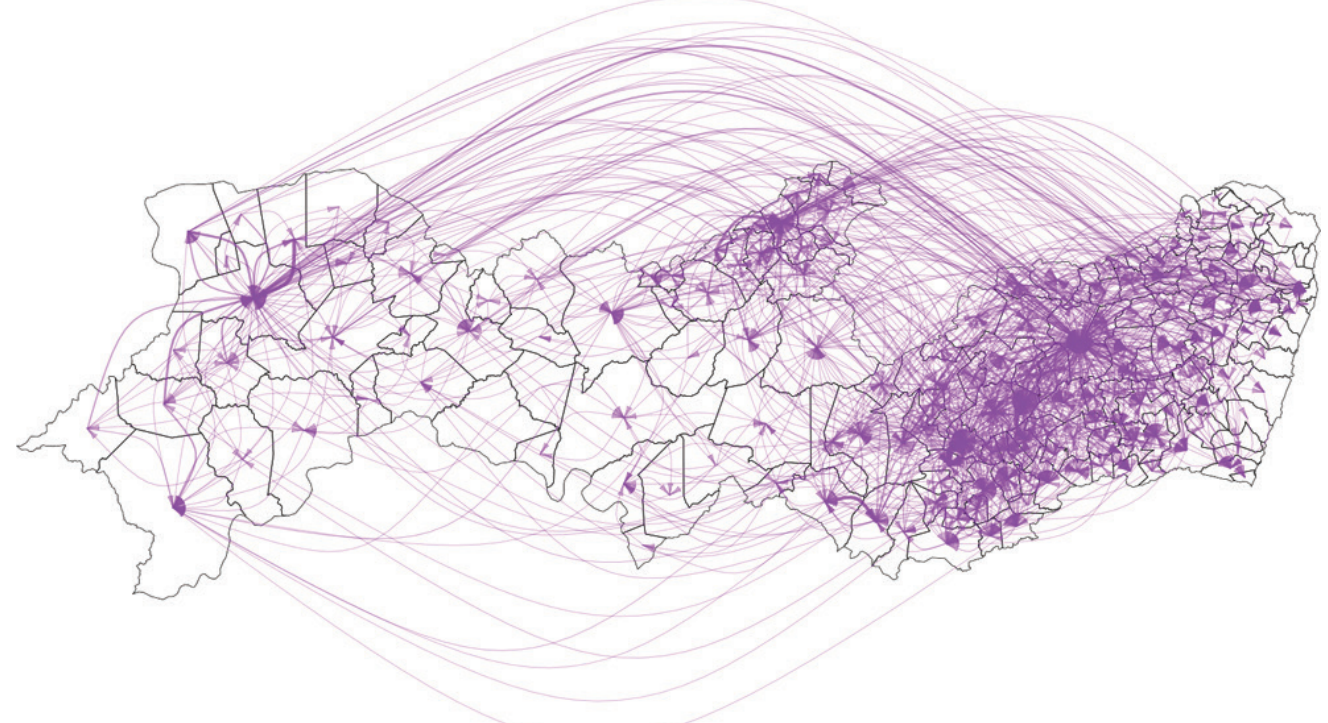

Figure 1 - A map of state of Pernambuco, Brazil, with lines showing the movement of cattle between the municipalities in June 2012 - Pernambuco - 2012

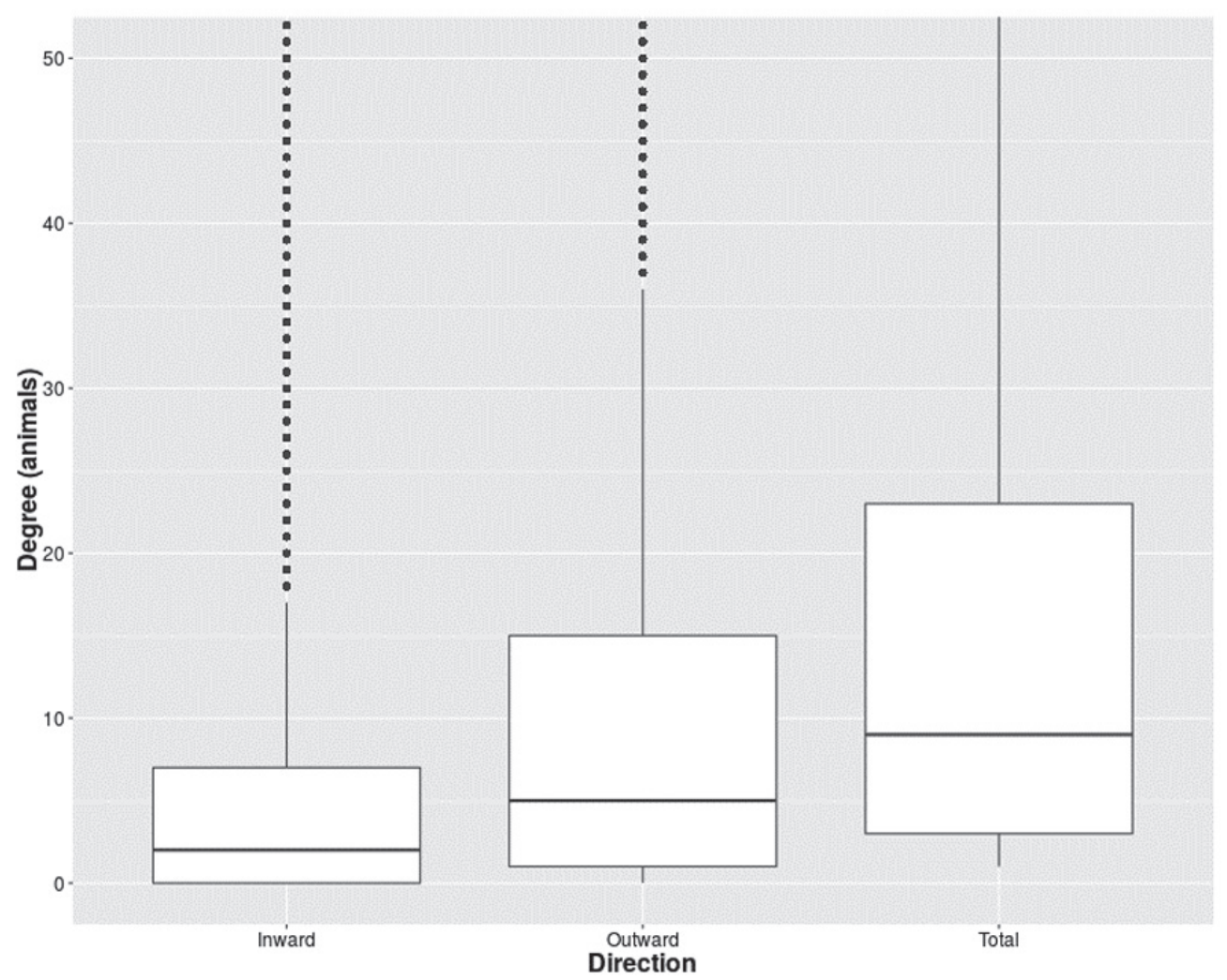

Figure 2 - Boxplots showing the number of animals moved per premise separated into groups of buying, selling, and total (the $y$-axis is limited to 50 animals) - Pernambuco 2012-2013 


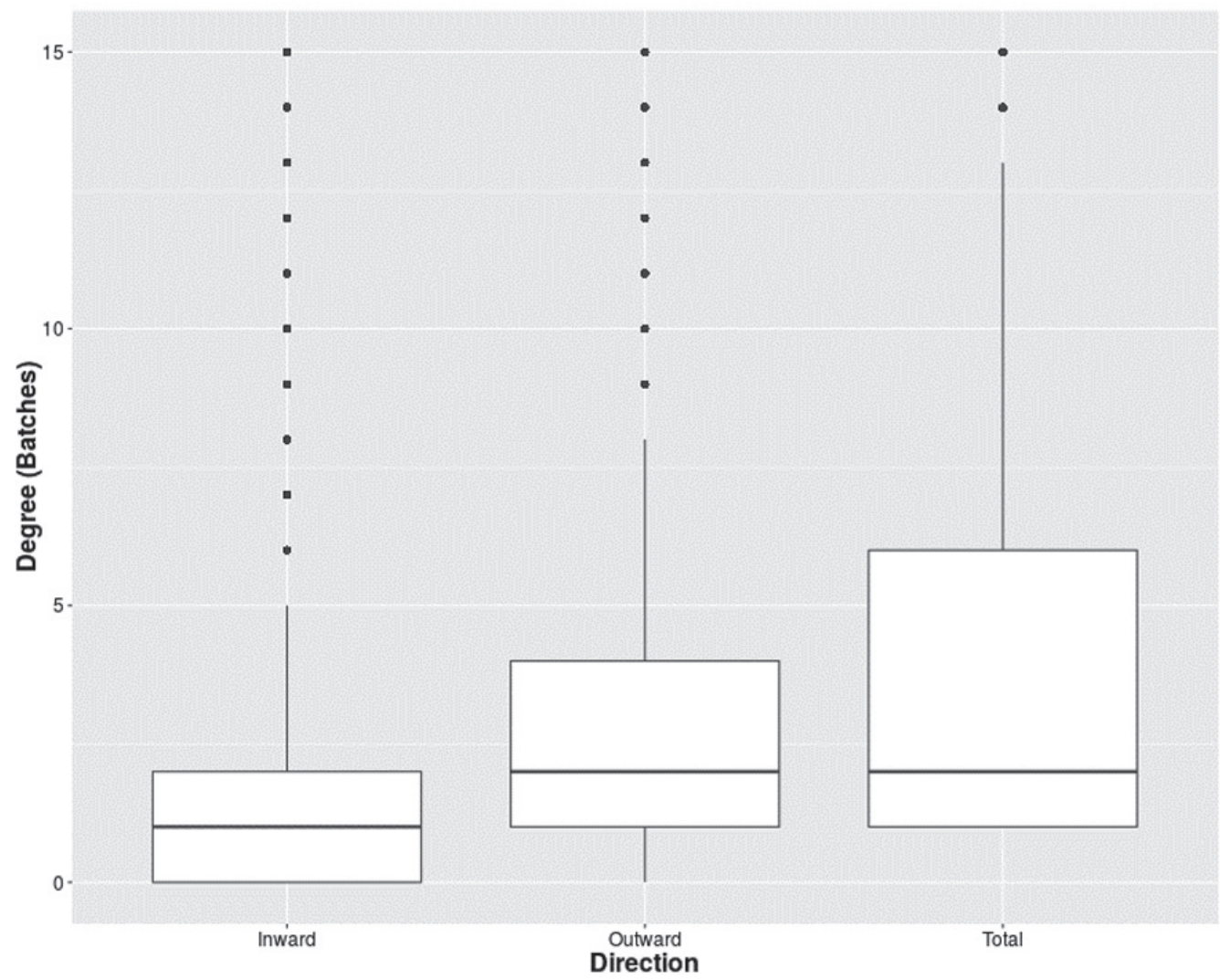

Figure 3 - Boxplots showing the total number of batches moved based on number of GTAs issued for each premise, separated into groups of buying, selling, and total (the $\mathrm{y}$-axis is limited to 15 batches) - Pernambuco - 2012-2013

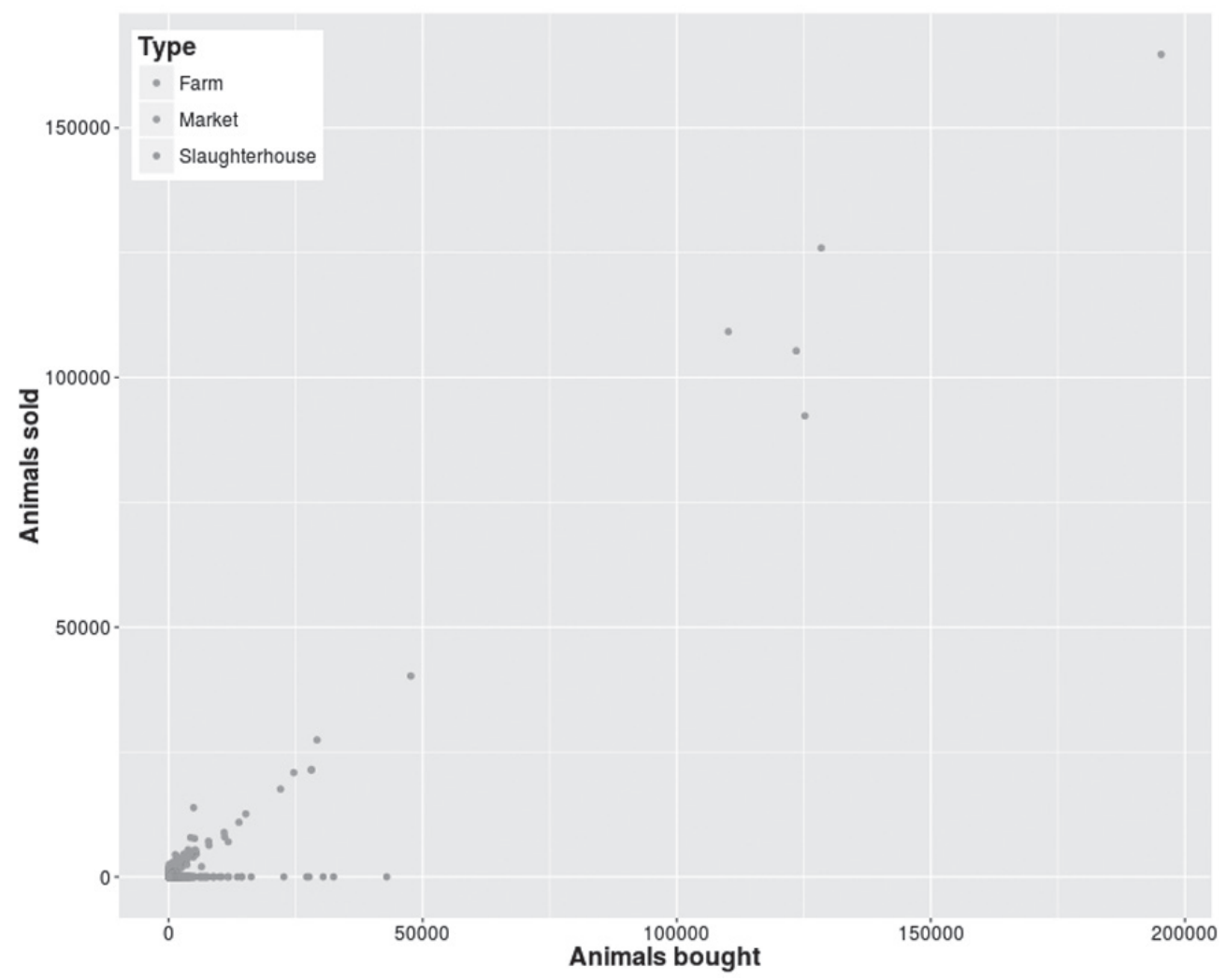

Figure 4 - A scatterplot showing the amount of cattle bought and sold, separating the premises by type - Pernambuco - 2012-2013 
The fitting of the degree distribution using the powerlaw is shown in figure 5, with each type of property represented by a different color. Notice that the highestdegree premises (green dots in the tail of the distribution) were livestock markets.
Figure 6 shows the percentage of movements based on the percentage of more-connected nodes. We observed that approximately $20 \%$ of the more-connected premises were responsible for approximately $87 \%$ of the movement related to sales and $95 \%$ of the movement related to purchases.

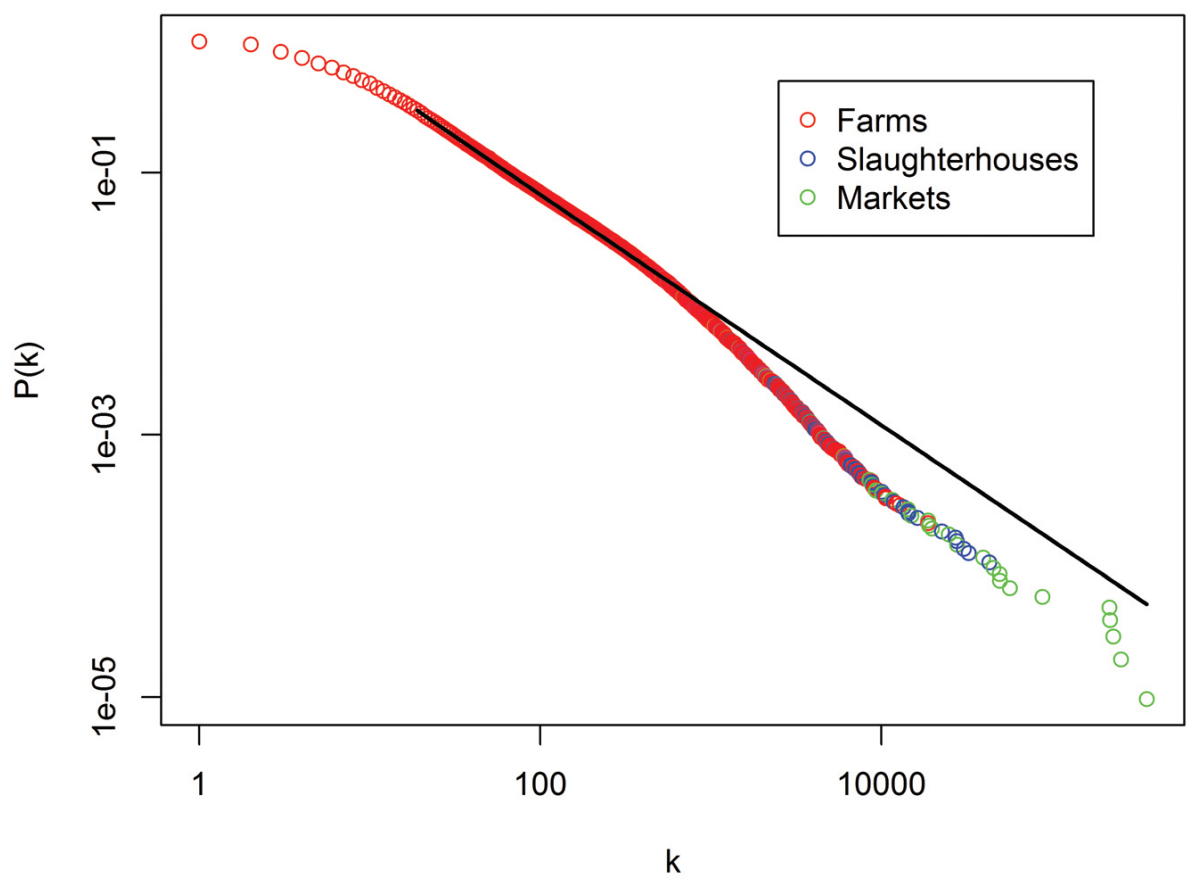

Figure 5 - The distribution of the premises' degrees showing the proportion of nodes with a certain degree (cattle traded) based on the type of premises on a logarithmic scale. The line is fitted based on the power law, with a fitting parameter of $\alpha=1.88$ and a minimum value for $k$ used in the fit $k_{\min }=19-$ Pernambuco - 2012-2013

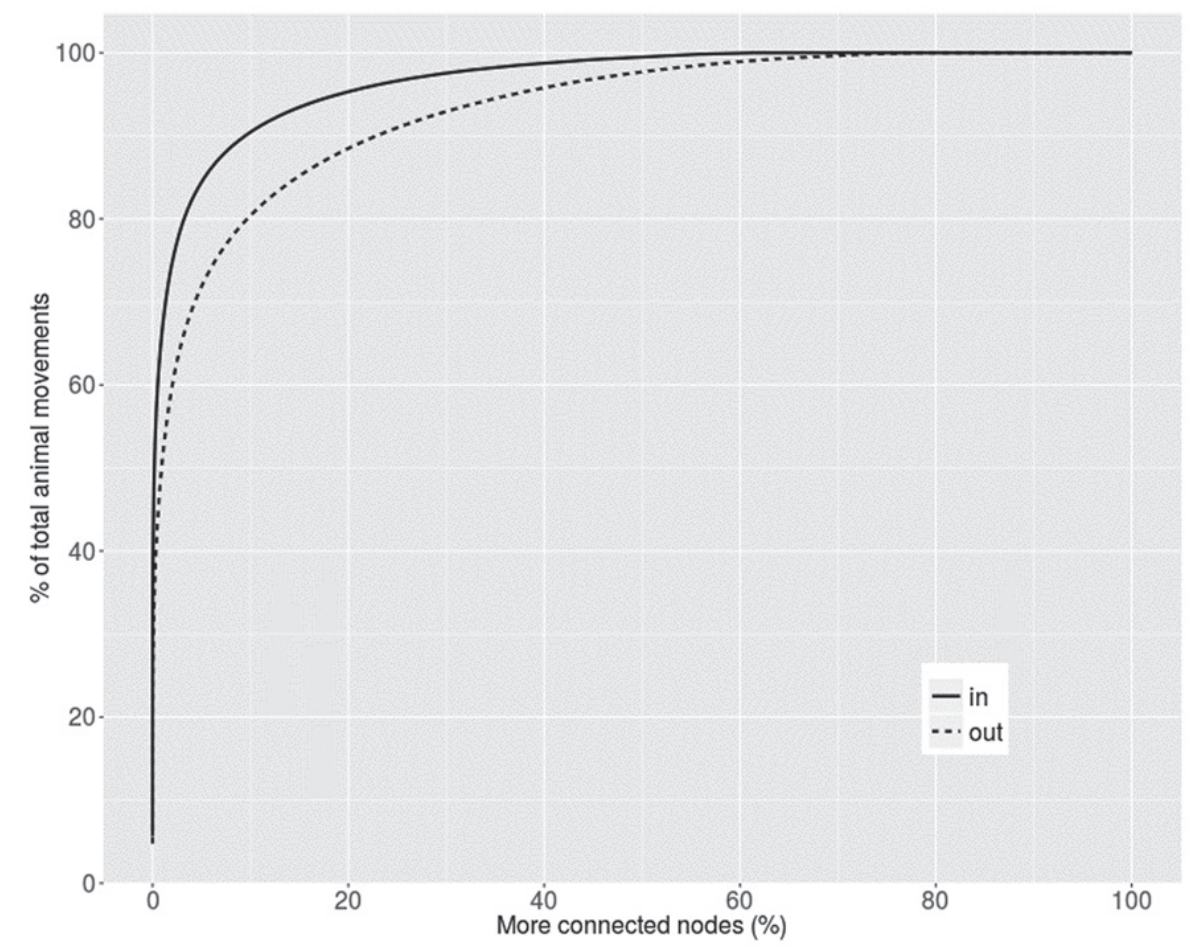

Figure 6 - Percentage of movements carried out by the more-connected premises Pernambuco - 2012-2013 
Figure 7 shows the distribution of the average degree of neighboring nodes (boxplot) as a function of the degree of the node. In general, this figure shows that the nodes with lower degrees are connected to the nodes with higher degrees; a disassortative behavior that should reflect, to a large extent, the movements between cattle premises that trade few animals and the markets.

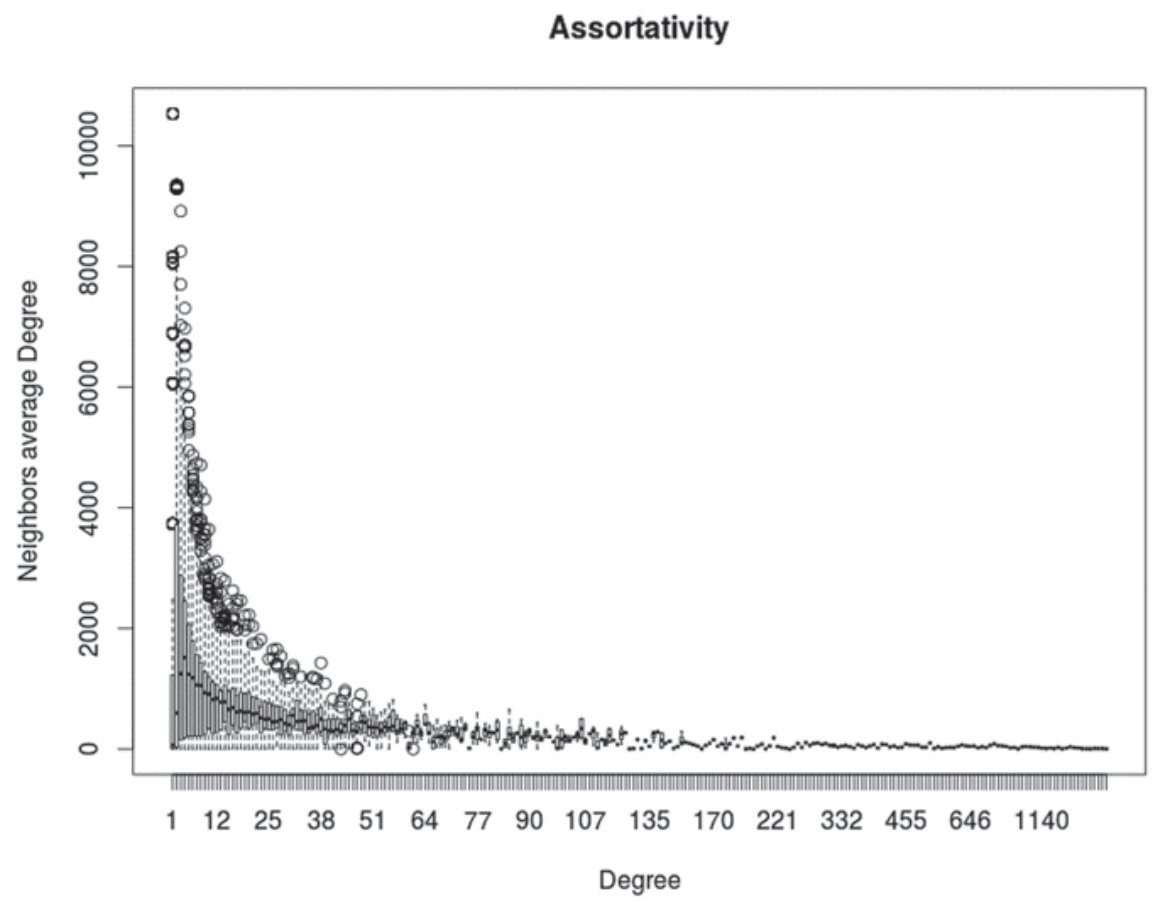

Figure 7 - The distribution of the average degree of the neighboring nodes (boxplot) as a function of node degree - Pernambuco - 2012-2013

\section{Discussion}

This research represents the first study that characterizes the cattle movement network in Pernambuco and in the Northeast macro-region of Brazil. Moreover, it presents important results that support the animal health surveillance actions coordinated by ADAGRO. Approximately $52.6 \%$ of the total cattle movement in 2012 and 2013 in Pernambuco involved the entrance to or exit from cattle markets, which reveals the epidemiological importance of these premises regarding the potential risks of disease transmission, despite representing only $0.17 \%$ of the network nodes.

Other cattle movement studies were performed in the Brazilian states of Mato Grosso (NEGREIROS, 2010; CAPANEMA et al., 2012; CIPULLO, 2013; GRISI-FILHO et al., 2013; CIPULLO et al., 2016), Mato Grosso do Sul (CAPANEMA et al., 2012), Paraná, and Santa Catarina (FELIPE et al., 2013). The state of Mato Grosso is part of the Central West region in Brazil, and, in 2014, was responsible for $33.5 \%$ of the Brazilian cattle herd along with its Central West neighboring states, Mato Grosso do Sul and Goiás (BRASIL, 2016). In the cattle movement network of Mato Grosso, Negreiros (2010) observed that the slaughterhouses were important hubs, followed by markets and big farms. It is worth mentioning that beef production for national and international consumer markets is an important economic activity in the state of Mato Grosso, where large-scale farms are responsible for most of the cattle production. In contrast, in Pernambuco the majority of the cattle production is in small scale and markets are important hubs. A pattern of small-scale production similar to that of Pernambuco is also observed in other states of the Northeast region of Brazil, where typical markets for trading cattle, pigs, goats, and other agricultural goods take place, and farmers are usually small-scale producers.

Markets may play key roles in the spread of infectious diseases in livestock movement networks (KAO et al., 2006). For instance, Robinson and Christley (2007) found that auction markets played an important role in foot- 
and-mouth disease outbreaks in Great Britain. Similarly to what we have observed in Pernambuco, markets were the key influential holdings in the network of Danish cattle movements (MWEU et al., 2013). In Cambodia, Poolkhet et al. (2016) found that the key players were producers who raise their cattle as backyard animals, which resembles the situation of many Pernambuco farmers. Given the importance of markets in the spreading of infectious diseases and the key role markets play in the cattle movement network in Pernambuco, effective targeted disease surveillance and control strategies should consider markets as relevant targets. Surveillance strategies, such as risk-based, indicator-based, early-warning, active, passive, and participatory surveillance (HOINVILLE et al., 2013) are examples of strategies that could benefit from using markets as potential targets to increase surveillance sensitivity in detecting cases or diseases.

In Mato Grosso and Mato Grosso do Sul GTAs were analyzed in order to identify the municipalities that received the highest amount of cattle destined for slaughterhouses, classifying them as the municipal centers for slaughter (CAPANEMA et al., 2012). In Paraná and Santa Catarina GTAs were analyzed to identify the micro-regions that receive the most cattle, classifying them as the central regions for slaughter or slaughter destinations (FELIPE et al., 2013). These methods of analysis differed from the present study performed in Pernambuco because the GTAs issued were analyzed for all purposes to characterize the movement network of cattle. Cipullo et al. (2016) applied another methodology, which also differed from the current study, in Mato Grosso in order to analyze and compare the cattle movement network from herds positive and negative for brucellosis. Negreiros (2010) conducted a study in Mato Grosso that was most similar to the current methodology used in PE, whose characterization of cattle movement was evaluated for various purposes. Table 5 shows the differences in the cattle movement variables between Mato Grosso and Pernambuco.

Table 5 - The differences in the cattle movement variables between Mato Grosso (2007) and Pernambuco (2012 and 2013 ) Pernambuco - 2012-2013

\begin{tabular}{|c|c|c|c|c|}
\hline Variables & $\begin{array}{c}\text { Mato Grosso } \\
\text { (NEGREIROS, 2010) }\end{array}$ & & $\begin{array}{l}\text { Pernam } \\
\text { (Present }\end{array}$ & \\
\hline Study Period & 2007 & 2012 & 2013 & 2012-2013 \\
\hline Number of cattle & $18,109,213$ & $1,688,585$ & $1,792,600$ & $3,481,185$ \\
\hline Number of batches & 536,830 & 372,521 & 365,429 & 737,950 \\
\hline Nodes & 76,277 & 79,910 & 71,796 & 103,351 \\
\hline Slaughter & $33.49 \%$ & $16.30 \%$ & $18.57 \%$ & $17.47 \%$ \\
\hline Finishing & $44.30 \%$ & $45.53 \%$ & $47.36 \%$ & $46.47 \%$ \\
\hline Participation in market* & $0 \%$ & $30.17 \%$ & $27.55 \%$ & $28.83 \%$ \\
\hline Reproduction & $21.94 \%$ & $7.46 \%$ & $5.83 \%$ & $6.62 \%$ \\
\hline Exhibition and Auction & $2.22 \%$ & $0.02 \%$ & $0.03 \%$ & $0.02 \%$ \\
\hline Export & $0 \%$ & $0.51 \%$ & $0.65 \%$ & $0.58 \%$ \\
\hline Other ${ }^{* *}$ & $0 \%$ & $0.002 \%$ & $0.004 \%$ & $0.003 \%$ \\
\hline
\end{tabular}

Legend: $\quad *$ The data used were only from the inflow of cattle.

${ }^{* *}$ Other variables: veterinary care, recreation, research, sanitary slaughter, leaving the slaughterhouse, and work

A comparison of the results of the two states revealed that the number of cattle moved in Pernambuco was 5.2 times smaller. The fact that the movement was analyzed over two years might have favored the appearance of a larger number of batches $(n=737,950)$; however, the number of batches moved was lower when considering the years 2012 and 2013 separately.

In 2012 the states in the northeastern region experienced a drought that might have influenced the dynamics of cattle movement, presenting 8,114 more nodes (connected and 
distributed in Pernambuco and in other states) than were found in 2013 (Table 5). This fact might be due to an attempt by the producers to dispose of their livestock to mitigate the damage caused by the severe drought.

Table 5 shows a few different percentages for the purposes of movement because the values for the variable "slaughter" reflect the importance of beef cattle in Mato Grosso, accompanied by higher numbers for exhibitions, auctions, and reproduction compared with PE, whose listed purposes do not have the same economic significance. However, cattle markets are important and peculiar to northeastern Brazil. These events draw a large flow of farm animals, and they occur weekly in most municipalities, which is a determining factor regarding the variable "farming/finishing". This variable was likely overestimated because the animals that entered these markets, when not sold, leave and return to their premises of origin with the purpose of "farming/ finishing". Furthermore, these animals participate in other markets in Pernambuco and neighboring states, especially Alagoas, Paraíba, Piauí, and Ceará.

Regarding the difference between the quantity of cattle that entered and exited the cattle markets (Tables 1 and 3) during the study period, two factors can be attributed: some of the GTA records issued manually were lost, and the actual quantity of the batch that entered the market might have been lower than which is stated in the GTA.

In Pernambuco $75 \%$ of the premises bought less than eight animals $\left(k_{\text {in }}\right)$ and sold no more than 15 animals $\left(k_{\text {out }}\right)$ (Figure 2). Thus, the scale of the cattle production system in Pernambuco is small if compared, for instance, to the production system in Mato Grosso, where $75 \%$ of the premises had equal to or fewer than 62 animals upon entrance and 143 animals upon exit [12].

The analysis of the cattle movement data in Pernambuco based on the degree of distribution revealed that after adjusting for the degree of distribution $\mathrm{P}\left(k_{\text {in }}\right)$ some premises bought cattle from a large number of premises and presented a higher value than that predicted by the power law. These premises were those that also had elevated numbers for the inflow of animals, such as slaughterhouses and cattle markets. After fitting for $\mathrm{P}\left(k_{\text {out }}\right)$, a small proportion of premises was revealed to have sold cattle to a high number of premises, demonstrating a value below that predicted by the power law (Figure 3). According to Negreiros (2010), the premises that had low $k_{\text {in }}$ and $k_{\text {out }}$ values for animal movement have direct influence over $\mathrm{P}\left(k_{\text {in }}\right)$ and $\mathrm{P}\left(k_{\text {out }}\right)$, respectively, for low values. In $\mathrm{PE}$ this characteristic can be attributed to family farming premises.

Several premises traded only a few cattle, and only a few premises traded several cattle; that is, $20 \%$ of the premises accounted for $87 \%$ of sales-related movement, and $95 \%$ of cattle purchases contributed to providing significance for the use of certain categories of premises that had high in-degree $\left(k_{\text {in }}\right.$ elevated $)$ and high out-degree $\left(k_{\text {out }}\right.$ elevated $)$ for epidemiological surveillance (for instance, monitoring activities could be performed at shorter time intervals on more connected farm premises). Thus, in addition to designing the first study on the characterization of the cattle movement network in Pernambuco and northeast Brazil, the present study provided information to better handle the strategies for the prevention, monitoring, and surveillance of relevant infectious diseases for the animal health protection system.

\section{Conclusion}

Analyzing the cattle movement network in Pernambuco we found that approximately $20 \%$ of the more-connected premises were responsible for approximately $87 \%$ of the movement related to sales and $95 \%$ of the movement related to purchases. Of the moved animals analyzed 52.57\% $(1,829,907 / 3,481,185)$ were involved in the movement of cattle in or out of livestock markets. These findings suggest that surveillance systems should highly benefit from targeting markets and especially from monitoring movements from highly connected premises to markets or vice-versa. Surveillance strategies could use such information to increase surveillance sensitivity in detecting cases or diseases, increasing the efficiency of the animal health surveillance system.

\section{Acknowledgements}

The authors thank ADAGRO-PE, the government of $\mathrm{PE}$, and all of the professionals and technicians who collaborated on the study. 


\section{References}

AGÊNCIA DE DEFESA E FISCALIZAÇÃO AGROPECUÁRIA DE PERNAMBUCO (ADAGRO).

Relatório da campanha de vacinação de febre aftosa: $1^{\text {a }}$ etapa de 2014. Recife: Adagro, 2014.

ALMEIDA, E.C. Situação epidemiológica da brucelose bovina no estado de Pernambuco. 2013. Tese ( $\mathrm{PhD}$ em Medicina Veterinária) - Departamento de Medicina Veterinária, Universidade Federal Rural de Pernambuco, Recife, 2013.

AMADOR, M. B. M.; CORRÊA, A. C. B.; BARBOZA, A. D. Contribuição da visão sistêmica ao estudo do espaço pecuário de Venturosa e Pedra no Agreste de Pernambuco. In: ENCUENTRO DE GEOGRAFOS DE AMÉRICA LATINA, 12., 2009, Montevidéu. Anais... Montevidéu: Editora de la Universidad de la Republica, 2009. p. 60-75.

AMAKU, M.; GRISI-FILHO, J. H. H.; NEGREIROS, R. L.; DIAS, R. A.; FERREIRA, F.; FERREIRA NETO, J. S.; CIPULLO, R. I.; MARQUES, F. S.; OSSADA, R. Infectious disease surveillance in animal movement networks: an approach based on the friendship paradox. Preventive Veterinary Medicine, v. 121, n. 3-4, p. 306-313, 2015. doi: 10.1016/j.prevetmed.2015.08.002.

BIGRAS-POULIN, M.; THOMPSON, R. A.; CHRIEL, M.; MORTENSEN, S.; GREINER, M. Network analysis of Danish cattle industry trade patterns as an evaluation of risk potential for disease spread. Preventive Veterinary Medicine, v. 76, n. 1-2, p. 11-39, 2006. doi: 10.1016/j. prevetmed.2006.04.004.

BRASIL. Ministério da Agricultura, Pecuária e Abastecimento. Departamento de Defesa Animal. Instrução Normativa no 18 , de 18 de julho de 2006. Diário Oficial da União, 20 Jul. 2006, Seção 1, p. 12.

BRASIL. Ministério da Agricultura, Pecuária e Abastecimento. Departamento de Saúde Animal. Projeto de ampliação de zona livre de febre aftosa com vacinação: relatório final. Brasília, DF: Mapa, 2013.

BRASIL. Rebanho bovino brasileiro cresce e chega a 212,3 milhões de cabeças de gado. Portal Brasil, 2016. Available from: http://bit.ly/1Q5epb8. Viewed: 8 Nov. 2016.
CAPANEMA, R. O.; HADDAD, J. P. A.; FELIPE, P. L. S. Trânsito de bovinos nos estados do Mato Grosso e Mato Grosso do Sul, Brasil. Arquivo Brasileiro de Medicina Veterinária e Zootecnia, v. 64, n. 2, p. 253-262, 2012. Available from: $<$ http://bit.ly/2fe0Kjj $>$. Viewed: 21 Sep. 2017.

CIPUlLO, R. I. Comparação e análise da rede de movimento de bovinos de propriedades positivas e negativas para brucelose no estado do Mato Grosso. 2013. 57 f. Dissertação (Mestrado em Ciências) - Faculdade de Medicina Veterinária e Zootecnia, Universidade de São Paulo, São Paulo, 2013. doi: 10.11606/D.10.2013.tde26042013-170717.

CIPUlLO, R. I.; GRISI-FILHO, J. H. H.; DIAS, R. A.; FERREIRA, F.; FERREIRA NETO, J. S.; GONÇALVES, V. S. P.; MARQUES, F. S.; NEGREIROS, R. L.; OSSADA, R.; AMAKU, M. Cattle movement network, herd size, and bovine brucellosis in the State of Mato Grosso, Brazil. Semina: Ciências Agrárias, v. 37, n. 5, p. 3777-3792, 2016. Supplement 2. doi: 10.5433/1679-0359.2016v37n5Supl2p3777.

CSARDI, G.; NEPUSZ, T. The igraph software package for complex network research. InterJournal Complex Systems, p. 1695, 2006. Available from: http://igraph.org. Access: 21 Sep. 2017.

FELIPE, P. L. S.; NICOLINO, R. R.; CAPANEMA, R. O.; HADDAD, J. P. A. Caracterização do trânsito bovino no estado do Paraná e Santa Catarina, Brasil, 2008. Arquivo Brasileiro de Medicina Veterinária e Zootecnia, v. 65, n. 3, p. 659-668, 2013. Available from: <http://bit. ly/2yghc9U>. Viewed: 21 Sep. 2017.

GILLESPIE, C. S. Fitting heavy tailed distributions: The poweRlaw package. Journal of Statistical Soft ware, v. 64, n. 2, p. 1-16, 2015. doi: 10.18637/jss.v064.i02.

GRISI-FILHO, J. H. H.; AMAKU, M.; FERREIRA, F.; DIAS, R. A.; FERREIRA NETO, J. S.; NEGREIROS, R. L.; OSSADA, R. Detecting livestock production zones. Preventive Veterinary Medicine, v. 110, n. 3-4, p. 304-311, 2013. doi: 10.1016/j.prevetmed.2012.12.013. 
HOINVILLE, L. J.; ALBAN, L.; DREWE, J. A.; GIBBENS, J. C.; GUSTAFSON, L.; HÄSLER, B.; SAEGERMAN, C.; SALMAN, M.; STÄRK, K. D. C. Proposed terms and concepts for describing and evaluating animalhealth surveillance systems. Preventive Veterinary Medicine, v. 112, n. 1-2, p. 1-12, 2013. doi: 10.1016/j. prevetmed.2013.06.006.

KAO, R. R.; DANON, L.; GREEN, D. M.; KISS, I. Z. Demographic structure and pathogen dynamics on the network of livestock movements in Great Britain. Proceedings of the Royal Society B, v. 273, p. 1999-2007, 2006. doi: 10.1098/rspb.2006.3505.

MWEU, M. M.; FOURNIÉ, G.; HALASA, T.; TOFT, N.; NIELSEN, S. S. Temporal characterisation of the network of Danish cattle movements and its implication for disease control: 2000-2009. Preventive Veterinary Medicine, v. 110, n. 3-4, p. 379-387, 2013. doi: 10.1016/j. prevetmed.2013.02.015.

NEGREIROS, R. L. Caracterização e análise da rede de movimento de bovinos no estado de Mato Grosso. 2010. 121 f. -Tese (Doutorado em Ciências) - Faculdade de Medicina Veterinária e Zootecnia, Universidade de São Paulo, São Paulo, 2010. doi: 10.11606/T.10.2010.tde12062012-144132.

NOOPATAYA, S.; THONGRATSAKUL, S.; POOLKHET, C. Social network analysis of cattle movement in Sukhothai Province, Thailand: a study to improve control measurements. Veterinary Medicine International, v. 2015, article ID 587252, 2015. doi: 10.1155/2015/587252.

PENA, C. S. Análise das redes de trânsito animal integrada à simulação da difusão de enfermidades infecciosas. 2011. 141 f. Dissertação (Mestrado em Estatística) - Departamento de Estatística Universidade Federal de Minas Gerais, Belo Horizonte, 2011.
POOLKHET, C.; KASEMSUWAN, S.; SENG, S.; KEARTHA, C.; SOKMAO, C.; SHIN, M.; KALPRAVIDH, W.; HINRICHS, J. Social network analysis of cattle movement in Kampong Cham, Kampong Speu and Takeo, Cambodia. Acta Tropica, v. 159, p. 44-49, 2016. doi: 10.1016/j.actatropica.2016.03.027.

R DEVELOPMENT CORE TEAM. R: A language and environment for statistical computing. Vienna: $\mathrm{R}$ Foundation for Statistical Computing, 2014. Available from: <http://bit.ly/2jNQhzW>. Viewed: 14 Jan. 2015.

RIBEIRO, K. P. P. Diagnóstico dos bovinos abatidos no frigorífico da região Centro-Sul do Mato Grosso e Influência da cobertura de sombrite e aspersão nos currais de espera do frigorífico, nas características de qualidade da carne bovina. 2009. 72 f. Dissertação (Mestrado em Ciência Animal) - Faculdade de Agronomia e Medicina Veterinária, Universidade Federal de Mato Grosso, Cuiabá, 2009.

ROBINSON, S. E.; CHRISTLEY, R. M. Exploring the role of auction markets in cattle movements within Great Britain. Preventive Veterinary Medicine, v. 81, n. 1-3, p. 21-37, 2007. doi: 10.1016/j.prevetmed.2007.04.011.

SILVA JÚNIOR, J. L.; CORRÊA, F. N.; NASCIMENTO, D. L.; BURGOS, M. S. O.; MACHADO, M. B.; ALMEIDA, E. C. Perfil do trânsito de animais em feiras de gado do estado de Pernambuco durante o ano de 2011. In: CONFERÊNCIA NACIONAL SOBRE DEFESA AGROPECUÁRIA, 2012, Salvador. Anais... Salvador: Sociedade Brasileira de Defesa Agropecuária, 2012. p. 194.

WHITE, P.; FRANKENA, K.; O'KEEFFE, J.; MORE, S. J.; MARTIN, S. W. Predictors of the first between-herd animal movement for cattle born in 2002 in Ireland. Preventive Veterinary Medicine, v. 97, n. 3-4, p. 264-269, 2010. doi: 10.1016/j.prevetmed.2010.09.017. 